\title{
Why Community-Based Tourism and Rural Tourism in Developing and Developed Nations are Treated Differently? A Review
}

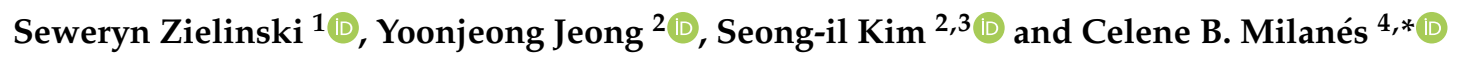 \\ 1 Department of Hospitality and Tourism Management, Sejong University, 209 Neungdong-ro, Gwangjin-gu, \\ Seoul 05006, Korea; zielinski@sejong.ac.kr \\ 2 Department of Forest Sciences, Seoul National University, 1 Gwanak-ro, Gwanak-gu, Seoul 08826, Korea; \\ yoonjeong522@snu.ac.kr (Y.J.); seongil@snu.ac.kr (S.-i.K.) \\ 3 Research Institute of Agriculture and Life Sciences, Seoul National University, 1 Gwanak-ro, Gwanak-gu, \\ Seoul 08826, Korea \\ 4 Department of Civil and Environmental, Universidad de La Costa, Calle 58\#55-66, Barranquilla 080002, Colombia \\ * Correspondence: cmilanes1@cuc.edu.co
}

Received: 30 June 2020; Accepted: 20 July 2020; Published: 23 July 2020

\begin{abstract}
Rural community tourism initiatives in developed nations share most positive and negative characteristics with community-based tourism (CBT) initiatives in developing nations. They also share many barriers and conditions for tourism development. What makes them different is the context in which they operate. This paper identifies the main conditions that explain these differences through a review of findings from 103 location-specific case studies and other available literature that provides empirical evidence. The paper also explores the usage of the concepts of CBT and rural tourism. The findings are discussed under seven categories: Definitions, socioeconomic and cultural factors, policy and governance, land ownership, community cohesiveness, assimilation of external stakeholders, and type of visitors. It is argued that it is the developing-/developed-nation context, and not objectively established criteria, which largely dictates authors' narratives with corresponding takes on tourism development and subsequent recommendations. The paper engages in a discussion about case-study research, its weaknesses and tendencies, providing some recommendations on how to increase the contribution of case studies to knowledge, and calls for more research on externally assisted non-Indigenous community-tourism initiatives in developed nations.
\end{abstract}

Keywords: CBT; remote area; peripherality; tourism development; rural development

\section{Introduction}

Community-based tourism (CBT) and other sub-branches of sustainable tourism centered in communities have been commonly applied as vehicles for rural development in peripheral areas. Their beginnings date back to the 1980s, when community-based tourism was believed to be an alternative for rural people in the South [1], and a viable instrument for poverty reduction, offering opportunities for conservation [2] and rural economic development [3]. Because of these benefits, many community-based tourism initiatives became community-development projects in developing nations [4]. Throughout the years, a considerable number of guidelines and project reports have been published by various organizations to facilitate the successful implementation of community-based tourism (e.g., [2,5-18]), many of which were designed to support development of tourism through official development assistance (ODA).

Despite the potential of tourism to generate welfare for communities, as well as social, economic, and cultural benefits in the long-run, many initiatives failed to deliver on their promises [19]. Many of 
those initiatives failed because of a combination of unfavorable conditions that were identified in the literature (e.g., [19-26]). Although these conditions were detected in developing and developed nations, scholars believe that, because of different economic, legislative, and political structures, they do not equally apply [27]. Thus far, studies such as that of Tosun [27] or Giampiccoli et al. [28] explored these differences from a theoretical perspective and the authors' own knowledge and experience. This paper gathered the findings from 103 location-specific case studies that provide empirical evidence of the critical conditions that differentiate community tourism in developing and developed nations (see Appendix A for more information about the case studies). The seven categories proposed in this paper are based on results of a content analysis of a smaller sample of case studies that identified 148 specific factors that facilitate and inhibit CBT in developing and developed nations (in press). Based on this extensive list of factors, seven categories were designed that encompass the key drivers behind these differences and provide some justification for differential treatment of CBT and rural tourism in developing and developed nations seen in the literature.

It is argued that it is the developing-/developed-country context, and not objectively established criteria, which largely dictates the authors' narratives with the corresponding takes on tourism development and subsequent recommendations. The paper engages in a discussion about the concept and definitions of CBT and rural tourism, the conditions that differentiates them, case-study research, and its weaknesses and tendencies, providing some recommendations on how to increase the contribution of case studies to knowledge. Only studies that encompassed entire small-scale destinations were considered in the review, while studies of rural tourism carried out on individual businesses were discarded.

\section{CBT and Rural Tourism: Definitions and Concepts}

In the context of developed nations, the concept of CBT has been used rather sporadically. However, according to various definitions of CBT, the concept is applicable to developed nations as well. Several scholars made an attempt to define the term CBT (e.g., [19,29-31]), concluding that CBT is 'tourism owned and/or managed by communities, and intended to deliver wider community benefit' [19] (p. 12). Although there are many definitions of CBT, the main aspects that characterize it are community control and management, conservation of culture and nature, empowerment, and community development $[19,32,33]$.

CBT initiatives can take many different forms and shapes. Depending on the level of community participation, they range from community employment in businesses, a joint venture between a community or family and an outside business partner, to full ownership/management of the tourism operation [29]. Saayman and Giampiccoli [34] noted that independent initiatives should be encouraged and could form part of a CBT initiative. By this definition, independent family-owned rural businesses could be considered to be CBT initiatives. CBT can also be categorized on the basis of single-communityand multiple-owned structures under a common organizational umbrella (e.g., [35]). The former model is based on activities around the nucleus of a lodge that often employs a rotation system, while the latter includes a variety of micro- and small enterprises that operate under a common organizational umbrella [36,37]. By this definition, independent family-owned rural businesses could be considered to be CBT initiatives only if they are governed by a community organization.

However, the concept of an umbrella organization is also problematic because of the array of possible arrangements within the organization. An organization composed of members driven by individual interests to carry out a specific economic activity to gain personal benefits is very different from an organization whose members act co-operatively in the interest and benefit of the community [38]. As such, the conception of community should be refocused around social interactions generated by individuals willing to pursue common interests, goals, and collective action rather than 'focus exclusively on local entities characterized by the ownership of common resources and/or on Indigenous socioterritorial-political structures governed by customary mechanisms of control and management' [39] (p. 515). In a similar vein, Piselli [40] argued that, while the spatial and social 
dimensions of community are important, a community must ultimately be considered as a network. From this perspective, small-scale tourism initiatives run by communities with or without an umbrella organization fit within most definitions of both rural tourism and CBT.

In terms of characteristics, CBT initiatives in developing nations are very similar to rural-tourism in developed nations. According to OECD's [41] definition of rural tourism, it should be comprised of small-scale enterprises, characterized by open space, availability of natural and cultural heritage, traditional practices, connections with local families, growth that is slow and organic, local control, and sustainability. While most authors focused on the aforementioned aspects, some linked rural tourism strictly with farm tourism and agritourism (e.g., [42,43]). In some countries such as Spain, legislation separates agritourism from rural tourism on the basis of the presence of farming activity [44]. Besides farming, agritourism destinations are characterized by a spatial scattering of accommodations (farms), while rural tourism can take place in villages and small towns.

Likewise, in CBT, the role of authenticity takes central importance. The concept is based on tourists' expectations of original experiences, which is particularly relevant to the field of cultural-heritage tourism [45]. Scholars describe rural tourism and CBT as being commonly centered on providing a genuine representation of lifestyles and cultures [46], including their distinctive sense of place and pride [47], and the favorable environment for personal contact between hosts and guests [48]. Moreover, the most commonly cited limitations of rural tourism are also very similar to those found in CBT. In this context, case studies identified the limited access of communities to funding and decision making, low level of human capital [49,50], poor infrastructure and dependency on traditional industries [22,42], negative sociocultural and environmental impact [48], and restricted access to labor markets [51,52], among others.

Peripherality is one of the factors that blurs the differences between developing and developed nations in terms of the conditions for the development of community tourism. The concept is relevant to many rural areas and CBT initiatives around the world. Besides the previously described characteristics of rural tourism, physical distance to larger agglomerations creates social, economic, and political isolation, and consequently a low level of autonomy in planning and development [52], low levels of economic vitality, lack of political power to influence decision making [53], and a lack of infrastructure and amenities [54]. When major decisions are taken by key economic and political institutions located in more central areas, people in the periphery often feel a sense of alienation and a lack of control over their own destiny [21,22]. Moreover, decision makers located in core areas tend to have a limited understanding of the relevant problems [55], often failing to acknowledge the possibility of alternatives to tourism [56].

\section{CBT and Rural Tourism: Similar Conditions, Different Treatment}

Case-study research is believed to be suitable for a comprehensive, holistic, and in-depth investigation [57] that can provide a more nuanced understanding of tourism development at the local level [58]. However, case-study research has to deal with some important limitations, of which perhaps the most significant is the subjective perception and the ideological approaches of their authors [59] that affect a range of factors, from definitions of concepts employed by their research through analysis, discussion, conclusions, and recommendations.

While most discussed CBT definitions acknowledge a variety of arrangements, the literature use them almost exclusively in a developing-nation context tied to project-based efforts characterized by the ownership of common resources and/or collective control and management. Some authors went as far as to state that CBT in Canada and Australia is used almost exclusively in the context of 'aboriginal/Indigenous tourism business' [60]. Others artificially limited the scope of CBT by adding aspects such as the promotion of customary and Indigenous cultures to their definitions (e.g., [61]). The concept of CBT began to appear in the literature in the 1990s, but its background dates back to the 1970s [29,31], when participatory development was introduced by international donors such as the United Nations and the World Bank in response to failures of traditional top-down approaches to 
development $[62,63]$. The usage of the term in the literature appears to be a legacy of project-based development assistance.

On the other hand, the concept of 'rural tourism' has principally been used in the literature in the context of developed nations, implying private ownership and the management of individual businesses in a rural setting. However, similar initiatives in a rural setting in developing nations are usually identified as CBT, ecotourism, or cultural-tourism initiatives. At first glance, it appears that the difference is strictly geographic location (developing vs. developed nation, remote peripheral vs. accessible, rural areas) and the type of natural or cultural attractions, but the literature review revealed that, in the case of small-scale destinations, the type of visitors (national/international/mixed) and their motivation (e.g., farm, rural lifestyle vs. wildlife watching, 'exotic' culture) are more suitable to explain the usage of the concept. On the other hand, larger-scale studies (area or region) tend to adopt the term 'rural tourism' to generalize all sorts of arrangements. Although the described usage of both concepts has not changed much since the 1990s, their meanings have been slowly evolving through embracing the notion of community around social interactions and networks, and the capacity of individuals to pursue common goals through collective action (e.g., [39,40,64]).

Other noticeable tendencies that stem from the previously discussed setting are the way in which authors write about tourism initiatives and critical conditions for their development. In a developing-nation context, there is a clear dominance of papers using cases of development-assistance projects ( $81 \%$ of analyzed case studies that stated the channel of initiation). Even though in both developing and developed contexts, many initiatives were started with external assistance $(81 \%$ and $60 \%$, respectively), project-based development assistance dominated in the former group, and governments' financial or technical assistance through programs and policies in the latter. The authors of case studies in both contexts identified the low capacity of local communities (e.g., [65-70]); technical support from third parties, including capacity building provided by NGOs or governments (e.g., [71-76]); and poor or inadequate policies (e.g., [46,67,77-79]), among many other aspects. If communities face similar barriers and conditions for tourism development, why are narratives of equity, distribution of benefits, (re)distributive institutional approaches, participative decision making, communal ownership, empowerment, and conflict resolution found almost exclusively in the developing-nation context?

\section{The Influence of Developing- and Developed-Nation Contexts}

\subsection{Socioeconomic and Cultural Factors}

Provision of income to communities living in areas of limited opportunities for the development of economic activities is the most basic objective of CBT that is well-suited for the economic regeneration of peripheral rural regions. Although present in both developing and developed countries, inequality and poverty pose varying levels of disadvantage in different nations [28]. Hence, some scholars make an important distinction between underprivileged socioeconomic contexts in developing and developed nations, stating that in the latter even underprivileged people are usually in a better position given by their access to infrastructure and other resources [28].

Indigenousness is one factor that complicates this distinction. Indigenous tourism is not only restricted by factors common for tourism development in remote areas [49,51], but also by the fact that Indigenous peoples are sidelined because of their minority status with their distinctive cultural traditions and internal institutions that are difficult to understand by their non-Indigenous counterparts [78]. According to Trau and Bushell [80], living conditions of Indigenous people in developed nations are often different to the non-Indigenous population. The consequences of colonialism have had a significant impact on Indigenous communities, leaving them in relative poverty in terms of the lack of human capital and limited access to decision making and funding [50,81]. From this perspective, those communities face similar conditions to communities in less developed nations. Despite this drawback, communities in developing nations enjoy access to welfare and programs designed specifically for disadvantaged groups living in the periphery (e.g., $[51,68,82,83])$. In consequence, 
their economic conditions are relatively better, as they rarely have to face absolute poverty [80]. A struggle to satisfy basic survival needs is one of the causes and consequences of poverty. However, poor socioeconomic conditions are also directly related to a lack of skills and knowledge required for tourism and low level of formal education, (e.g., [33,56,59,65-69,72,75,77,80,82,84-95]), and limited access to information to effectively engage in tourism planning and management (e.g., $[10,96,97])$. These limitations are prevalent in developing nations, although as noted previously, they are common in developed nations in the context of Indigenous tourism.

A limited understanding and knowledge of the tourism and travel industry is a community limitation identified in many cases studies in developing nations. Experiences show that the concept of tourism does not exist in all cultures (e.g., [10,98-100]). While people in developed nations usually have some sort of head start in tourism development due to their basic understanding of concepts, for many rural communities in developing nations, tourism is a recent phenomenon that challenges their traditional knowledge and understanding of the world. They are also facing the risk of losing cultural control because of the introduction of new activities that might not be entirely compatible with the local culture, which implies access to economic resources and often engagement with other stakeholders that may lead to conflicts [101].

\subsection{Policy and Governance}

Tourism-destination policy is regarded to be under the responsibility of public-sector stakeholders. Scholars argue that the intervention and regulation of the public sector is a requirement for effective management systems for tourism development [102-104]. Policies are designed with an objective to create an environment that maximizes stakeholders' benefits [105]. The lack of policy direction supporting community tourism has been identified as a limitation for CBT destinations around the world, such as Tanzania [77,106], Kenya [107], or Indonesia [24]. This issue is not only common in developing nations, but also in some remote areas of developed nations (e.g., [46,56,69,79]). Peripherality is a common issue for many remote communities that struggle to gain local governments' interest, and financial and administrative support. Such areas are viewed by leaders as unimportant and secondary for immediate action [100]. In consequence, policy actions are often unaligned with the needs and priorities of distant communities [55].

Nonetheless, case studies in mostly developed nations highlight governments' efforts to boost economies and revitalize rural areas through programs and policies that have had a positive effect on community-tourism initiatives (e.g., [58,70,76,79,83,94,108-110]), for example, Australia's attempt at closing the economic and quality-of-life gap between Indigenous and non-Indigenous citizens by integrating them into capitalist economies through policies aimed at economic support and the provision of livelihood opportunities [111]. Although very complicated and far from perfect, there are a number of government-assistance packages available for Indigenous people to start a business [51]. In a similar vein, many rural-tourism initiatives in developed nations can count on national or regional funds to start up community-based initiatives. In Europe, for example, new policies for rural areas were implemented to achieve a balance between traditional agriculture and nature preservation, as well as to revitalize rural and economically depressed areas [112]. The national policies implemented by most EU members are often supplemented by regional policies for the revitalization of rural areas, and territorial cohesion between core and 'disadvantaged' areas in the periphery [52].

Because public funds for supporting small scale rural initiatives are limited in many developing nations, NGOs and official-development-assistance (ODA) organizations are in position to provide support for community-based projects, but usually for a limited period of time. Moreover, case studies show that, without central management, organizations run by communities and nongovernmental partners have the limited ability to co-ordinate actions with the local government, to attract scarce public resources, or to secure a public budget to market the destination [26]. It has been widely recognized that project-based, short-life-cycle support for CBT in developing nations is one of the most common reasons for those initiatives to fail [26]. Governments, on the other hand, have power to 
execute long-term programs and directly engage in local development without relying on short-term objectives [113]. A strong and well-funded public sector also provides infrastructural development, including signage, marketing, and heritage interpretation [48].

However, not all governments and even NGO consultants have the required skills and knowledge of tourism development to initiate and lead tourism development (e.g., $[86,87,90,92,95,114,115]$ ). As noted by Ruhanen [104] in an Australian case, because the local government traditionally assumed that role, it can be argued that it has also accumulated a certain amount of experience and skills in supporting tourism development. The experience and tradition of public-private collaboration in tourism development in rural and peripheral areas gives an advantage to many developed nations that managed to create a socioeconomic and institutional setting that favors this type of development. As argued by Keyim [69], achieving it requires a considerable history of civil society and democracy built on low levels of corruption and high levels of trust between public and private stakeholders [69].

\subsection{Land Ownership}

Land ownership has a long tradition in developed nations. Hence, the majority of community-based initiatives are developed on individually owned private land. On the contrary, in developing nations, communal lands are more prevalent, and it is not uncommon that the community has no secured land tenure (e.g., $[91,116])$. Those communities living within protected areas have to make contractual arrangements with the government to use land and resources for tourism (e.g., $[65,66,91,93])$. Land tenure allows communities to decide on the desired land use, activities, and type of development. Without the ownership, the operations in the area can be either highly restricted or forbidden entirely. Furthermore, the lack of land tenure limits potential outside investments in infrastructure and facilities. Coria and Calfucura [117] state that communities can participate in CBT in the absence of land ownership, but this outcome is highly dependent on other favorable conditions; in reality, the lack of community control prevents communities from investing. Many case studies described the struggle for territory in the context of tourism (e.g., [24,77,106,118-120]).

Lack of land ownership does not have to necessarily play the role of a barrier for community-tourism development. Although collective ownership does restrict land availability for private ventures [101], contractual arrangements with the land owner (usually the government) that give the right for the collective control of land and resources, and collective land ownership provide some advantages that private ownership does not. The experiences from case studies showed that collective land ownership provides more favorable conditions for decision-making freedom, and accordingly better control over land and tourism development (e.g., [66,86,88,90,92,120-126]). At the same time, collectivity seems to decrease conflicts over land, because it cannot be individually owned and sold. On the other hand, under individual land ownership, the freedom to control tourism development is limited because land ownership is more prone to manipulation by external actors based on individual owners' decisions to keep or sell the land (e.g., [45,70,77,127-129]).

\subsection{Community Cohesiveness}

Case studies demonstrate that collectively owned and managed initiatives dominate the tourism in traditional communities (ethnic, rural, or Indigenous) in developing countries. As a result of high social capital and/or strong social hierarchy, the cohesiveness in these communities is relatively high. It is further illustrated by the employment of sharing work/benefit mechanisms that are often used for building tourism infrastructure and tourism cost/benefit sharing (e.g., [55,72-74,86,91,92,121,122,125,130-132]). Cohesiveness does not, however, mean that communities can be treated as one entity, as they are composed of individuals with different priorities and views on local development [94].

While modern rural communities in developed nations sometimes also display high cohesiveness and the ability to closely work together (e.g., [89,109,133-136]), there is a higher level of individuality and expectations to invest and operate independent businesses according to the rules of modern economy. Rural-tourism development has often been led by the individual efforts of an operator 
(a farm/land/accommodation owner), and then followed by other members of the community [42]. Because rural people in developed nations are more likely to have access infrastructure, facilities, the media, and education, cases of tourism initiation by the community without or with limited external support are common (e.g., $[79,109,128,134,136,137])$ as local actors are often capable of selecting their own actions to secure strategic advantages of the opportunities presented by rurality and/or periphery [52]. Funded externally, characterized by a low capacity to operate tourism, community initiatives in developing nations are rarely given that choice, or deliberately choose the model on the basis of communal ownership that requires strong ties created by socially meaningful relationships based on trust. These types of relationships are possible and highly advisable in the context of developed nations [64], but they are less common and usually only happen in tight-knit communities.

\subsection{Assimilation of External Stakeholders}

Because of crumbling agricultural activity and limited job opportunities in many rural areas around the world, there is a sustained population drift from those areas to urban centers [22]. At the same time, a comparative lack of innovation and progress in the peripheries, and the availability of natural resources are seen by people from core areas as a business/lifestyle opportunity (e.g., [109,138,139]). Besides a generally good understanding of tourism and business in general, these lifestyle entrepreneurs have advantage over the local people in terms of the education, skills, and resources to invest in tourism [133]. In developed nations, 'ex-urbanites', 'weekenders'. or second-home owners are leading groups composed mostly of country nationals from highly urbanized areas that often carry a set of values and images of rural communities from the past (such as a rural idyll) [42]. In developing nations, the group of 'lifestyle entrepreneurs' is composed largely of foreign nationals that might deepen the cultural gap between local and nonlocal entrepreneurs [26].

In traditional communities, foreign investors are seen as outsiders, and are generally not easily accepted due to cultural differences. The assimilation is further complicated when 'newcomers' compete with local people for visitors. In consequence, conflicts are not uncommon that might lead to rejection of foreigners, and a strong internal division within the community [140]. The literature on the topic highlights that newcomers and local people perceive each other to be very different, which often reflects conflicting ideas of each group's desires and needs [141]. In many cases, 'newcomers', driven by their own image and expectations of idyllic life, oppose modern development sought by the community [42]. Because of conflicts, those areas become heterogeneous spaces, and in some cases, dual societies comprising locals and migrants are created [140]. The way in which communities deal with conflicts also has a cultural underpinning, with two idealized approaches identified on the basis of individualistic and collectivist cultures [142]. Individualistic cultures deal with conflicts in a more dispassionate, straight-to-the-point way, while in collectivist cultures, conflict is culturally bound, viewed as a destructive force, and resolved in a more emotive way [143]. Hence, it can be argued that the assimilation of 'lifestyle entrepreneurs' in an individualistic cultural context is easier than the assimilation of individuals that do not share the same cultural background.

Despite many differences, the ability to collaborate and act for the common good is perhaps the most important factor leading to the acceptance of 'outsiders', and fostering social capital and sense of community [144]. Such purposive action, however, cannot occur if interactions between different groups constituting the community are limited or constrained [145]. Community building in such destinations is a complicated process, 'constantly affected by a lack of communication that blocks the emergence of common interests and collective action' [109] (p. 516). The experiences from case studies demonstrate that external stakeholders are able to integrate successfully in the absence of significant cultural differences, and when services offered by outsiders complement the local ones rather than compete with them. This, however, has principally been reported in developed nations (e.g., $[109,127,139])$.

Newcomers are accepted by the community because they bring skills and the capacity to connect the destination with the outside world, and tap into different tourism activities in which local people 
typically do not engage, and that requires skills and large capital investment (hotels and tour-operating enterprises). On the other hand, local initiatives focus on activities that are familiar and require limited investment (restaurants or community accommodation). For complementarity to occur, however, it is necessary for newcomers to not engage in the same activities, competing with the local population, and that the locals have enough skills and resources to engage in those complementary activities. Case studies showed that this is rarely the case in developing nations, not only because of the lack of those conditions, but also because of a low influx of visitors and operation at low occupancy rates, even after years of operation [146], which consequently increases local competition for visitors.

Due to much less pronounced cultural differences between communities and newcomers in developing nations, assimilation is often much smoother, and outsiders slowly become part of the community. In less traditional communities, people have usually had contact with the outside world for generations across centuries. New forms of mobility, a result of globalization, have strengthened the complexity of communities [139]. There is a constant exchange of people who may leave the community and emigrate somewhere else, while at the same time, new inhabitants may arrive to settle or live at the location for a period of time [141].

\subsection{Type of Visitors}

Two important factors that effectively differentiate community initiatives in the rural areas of developed nations and CBT in developing nations are the type of visitors and their motivation to travel. Although there is a certain overlap in motivations to travel to seek new experiences, and rural lifestyles and settings, rural tourism in developed nations is largely driven by the familiar image of the idyllic 'picturesque', 'peaceful', and 'friendly' countryside [42], while motivations to visit CBT initiatives run by Indigenous or traditional communities are more related with experiencing novelty, and searching for the unknown and learning about it [78]. Hence, scholars have claimed that cultural proximity decreases domestic demand for Indigenous cultures [78]. Because cultural proximity is usually related with physical distance from visitor-generating centers, case studies showed that CBT initiatives in developing nations attract mostly foreign tourists, while rural initiatives in developed nations attract domestic markets that do not need to travel large distances, and are easier to reach without targeted marketing.

\section{Final Remarks}

According to the definitions, the concepts of CBT and rural tourism are not much different from each other, as they both refer to family-/individually run businesses with a greater or lesser degree of co-ordination intended to deliver community benefit. They also share most of the positive characteristics and limitations. What makes them different is the context in which they operate. This paper identified and described the main conditions responsible for these differences through a review of case studies in developing and developed nations. These differences explain most tendencies in the narrative of case studies in developing and developed nations, including the authors' decisions to omit or focus on certain critical factors for community-tourism development. In other words, more often than not, case studies fall into specific categories with their corresponding takes on tourism development and subsequent recommendations.

It can be argued that this is the reason why certain strategies, for example, shared community infrastructure with a rotation system or another mechanism for sharing benefits that are often proposed by consultants in developing nations, are never proposed to underprivileged rural communities in developed nations, despite favorable conditions for such arrangements such as low capacity of local people, the lack of financial resources, and the availability of external funding (through rural-development policies and programs). Would strategies proposed in the context of developing nations be effective in developed nations, and which ones?

While in the case of externally initiated project-based tourism initiatives that are common in developing countries, the technical and financial assistance are guaranteed, publicly funded tourism 
initiatives in developed countries usually provide funds, but the technical assistance is less common due to the private character of most benefitting stakeholders. Hence, besides the access to welfare and public funds for local development in developed countries, there should be also emphasis on community-centered projects that provide capacity building and direct expert assistance to participating families. This role could be assumed by an umbrella organization managing the publicly funded initiative that oversees the project and provides direct assistance converting a rural tourism initiative to a CBT initiative. Unfortunately, the question of the effectiveness of strategies that are commonly employed in developing countries but rarely in developed nations remains unanswered because studies of externally assisted non-Indigenous community-tourism initiatives in developed nations are extremely scarce. Although this paper addressed the most common reasons for those arrangements not being proposed, the lack of empirical evidence of employed strategies in different contexts warrants further investigation.

Another implication of the findings is that in the absence of individual land rights, collective land management can be equally or in some cases even more beneficial because it gives decision-making freedom about the desired tourism development and control over the land use. Collective ownerships allow communities to pinpoint and invite specific stakeholders to operate in the area based on their complementary role, limiting potential competition. In the case of private land ownership, the optimal solution for the maintenance of control over and coherent tourism development is an umbrella destination management organization that gathers stakeholders around common goals for tourism development.

Another aspect that requires addressing is the fact that many case studies were missing the level of detail required to analyze differences between developing- and developed-nation settings. Given the variety of topics employed by the case studies (see the Appendix A), it is recognized that not all studies set out to identify key characteristics that positively or negatively influenced tourism development. However, even the studies that did focus on description of factors for 'success' or 'failure' of tourism based on the authors' own assessment, often provided a limited description of the conditions. Although this aspect is dealt with elsewhere [147], some topics were under-represented and require further research attention: The role of political will, the integration of 'outsiders' into communities, strategies employed to resist external pressures, and the role of cultural/ethnic divisions within a community, alliances and co-operation with other communities, the nonmonetary cost of involvement in tourism, the distribution of public resources among local stakeholder groups, land ownership and shared ownership arrangements, the types of networks within destinations, and internal mechanisms for conflict resolution.

The analysis was further skewed by a clear tendency towards research on Indigenous and ethnic communities in both developing and developed nations, and a clear under-representation of studies of small rural communities in developed nations. Despite a fair number of studies on rural tourism, most case studies focus on larger geographic areas of either small towns of roughly 4000 to 20,000 inhabitants, various villages, and larger rural regions. Studies that make in-depth qualitative analysis of small rural-tourism initiatives are still few and far between. With case-study research becoming 'somewhat disregarded or discredited in recent years' [148] (p. 740), there is little hope that this gap will be bridged anytime soon despite the undeniable value in qualitative approaches that aim at understanding tourism in rural areas.

Author Contributions: Conceptualization, S.Z. and S.-i.K.; methodology, S.Z.; investigation, S.Z., Y.J., and C.B.M.; resources S.-i.K.; writing—original draft preparation, S.Z.; writing-review and editing, Y.J. and C.B.M.; supervision, S.-i.K. All authors have read and agreed to the published version of the manuscript.

Funding: This research received no external funding.

Conflicts of Interest: The authors declare no conflict of interest. 


\section{Appendix A}

Table A1. Case Studies Reviewed in the Paper.

\begin{tabular}{|c|c|c|c|}
\hline No. & Author(s) & Location & Focus of the Study \\
\hline \multicolumn{4}{|c|}{ DEVELOPING NATIONS } \\
\hline 1. & Amati (2013) [149] & Kenya & Community participation in an ecotourism initiative \\
\hline 2. & $\begin{array}{l}\text { Anand, Chandan, } \\
\& \text { Singh (2012) [84] }\end{array}$ & India & Role of community homestay initiative in local development \\
\hline 3. & Belsky (1999) [150] & Belize & Influence of politics in a community-based rural ecotourism project \\
\hline 4. & $\begin{array}{c}\text { Bruyere, Beh, } \\
\text { \& Lelengula (2009) [114] }\end{array}$ & Kenya & $\begin{array}{l}\text { Perceptions of protected area leadership } \\
\text { and members of the communities }\end{array}$ \\
\hline 5. & Charnley (2005) [106] & Tanzania & $\begin{array}{c}\begin{array}{c}\text { Conditions for transformation of nature tourism in protect areas (PA) } \\
\text { into community ecotourism }\end{array}\end{array}$ \\
\hline 6. & $\begin{array}{l}\text { Chili \& Ngxongo } \\
\text { (2017) [98] }\end{array}$ & South Africa & $\begin{array}{l}\text { Challenges of community participation in } \\
\text { tourism development }\end{array}$ \\
\hline 7. & $\begin{array}{l}\text { Clements et al. } \\
\text { (2008) [66] }\end{array}$ & Cambodia & Lessons learned from a community-based tourism (CBT) initiative \\
\hline 8. & $\begin{array}{l}\text { Cobbinah, Black, } \\
\text { \& Thwaites (2015) [67] }\end{array}$ & Ghana & Implementation of ecotourism in a conservation area \\
\hline 9. & Cole (2006) [85] & Indonesia & Community participation towards empowerment \\
\hline $\begin{array}{l}10 . \\
11 .\end{array}$ & $\begin{array}{l}\text { Collins \& Snel } \\
\text { (2008) [86] }\end{array}$ & South Africa & $\begin{array}{l}\text { Official development assistance (ODA) experiences and lessons } \\
\text { learned from CBT development and management }\end{array}$ \\
\hline 12. & Colvin (1994) [122] & Ecuador & Assessment of a community-based ecotourism program \\
\hline 13. & Foucat (2002) [121] & Mexico & $\begin{array}{c}\text { Assessment of the sustainability of a community-based } \\
\text { ecotourism initiative }\end{array}$ \\
\hline 14. & Gascón (2013) [59] & Peru & Limitations of CBT as an instrument of development cooperation \\
\hline 15. & $\begin{array}{l}\text { Giampiccoli, Jugmohan, } \\
\text { \& Mtapuri (2014) [87] }\end{array}$ & South Africa & Community capacity building in tourism \\
\hline 16. & $\begin{array}{l}\text { Grieves, Adler, \& King } \\
\text { (2014) [88] }\end{array}$ & Mexico & $\begin{array}{l}\text { Community control, community characteristics, and inter-community } \\
\text { coalitions in ecotourism projects }\end{array}$ \\
\hline 17. & $\begin{array}{l}\text { Hernandez Cruz et al. } \\
\quad \text { (2005) [114] }\end{array}$ & Mexico & $\begin{array}{l}\text { Social and economic adjustment processes in introduction of } \\
\text { ecotourism in a community }\end{array}$ \\
\hline 18. & $\begin{array}{l}\text { Hitchner et al. } \\
\text { (2009) [151] }\end{array}$ & Malaysia & $\begin{array}{l}\text { Current state and challenges of community-based } \\
\text { transboundary ecotourism }\end{array}$ \\
\hline 19. & $\begin{array}{l}\text { Isaac \& Wuleka } \\
\quad(2012)[71]\end{array}$ & Ghana & Community perceptions of tourism development \\
\hline 20. & $\begin{array}{l}\text { Jamal \& Stronza } \\
\text { (2009) [130] }\end{array}$ & Bolivia & Tourism and community-parks partnerships in protected areas \\
\hline 21. & $\begin{array}{l}\text { Jamieson \& Sunalai } \\
\quad(2005)[72]\end{array}$ & Thailand & Sustainable tourism planning and management \\
\hline 22. & $\begin{array}{l}\text { Jitpakdee \& Thapa } \\
\text { (2012) [118] }\end{array}$ & Thailand & Sustainability analysis of ecotourism \\
\hline 23. & Jones (2005) [152] & Gambia & $\begin{array}{l}\text { Role of social capital in development of a community-based } \\
\text { ecotourism venture }\end{array}$ \\
\hline 24. & $\begin{array}{l}\text { Kim, Park, \& } \\
\text { Phandanouvong } \\
\text { (2014) [153] }\end{array}$ & Laos & Barriers to local residents' participation in community-based tourism \\
\hline 25. & $\begin{array}{l}\text { Knight \& Cottrell } \\
\quad \text { (2016) [154] }\end{array}$ & Peru & Processes of tourism-linked empowerment in communities \\
\hline 26. & $\begin{array}{c}\text { Kontogeorgopoulos, } \\
\text { Churyen, \& } \\
\text { Duangsaeng (2014) [73] }\end{array}$ & Thailand & Success factors in community-based tourism \\
\hline 27. & Lapeyre (2010) [131] & Namibia & $\begin{array}{c}\text { Contribution of CBT enterprises to poverty alleviation } \\
\text { and empowerment }\end{array}$ \\
\hline 28. & Lenao (2015) [115] & Botswana & Challenges facing community-based cultural tourism development \\
\hline 29. & Lepp (2007) [123] & Uganda & Residents' attitudes towards tourism \\
\hline
\end{tabular}


Table A1. Cont.

\begin{tabular}{|c|c|c|c|}
\hline No. & Author(s) & Location & Focus of the Study \\
\hline 30. & $\begin{array}{l}\text { Lima \& d'Hauteserre } \\
\quad \text { (2011) [65] }\end{array}$ & Brazil & Role of community capitals in ecotourism development \\
\hline 31. & $\begin{array}{l}\text { Matarrita-Cascante, } \\
\text { Brennan, \& Luloff } \\
\text { (2010) [155] }\end{array}$ & Costa Rica & $\begin{array}{l}\text { Local social interactional elements necessary for achievement of } \\
\text { sustainable tourism practices }\end{array}$ \\
\hline $\begin{array}{l}32 . \\
33 .\end{array}$ & $\begin{array}{l}\text { Mitchell \& Eagles } \\
\quad(2001)[132]\end{array}$ & Peru & Level of integration of communities in the local tourism sector \\
\hline 34. & $\begin{array}{l}\text { Moswete, Thapa, \& } \\
\text { Child (2012) [120] }\end{array}$ & Botswana & $\begin{array}{l}\text { Attitudes and opinions of local and national public sector } \\
\text { stakeholders towards community participation in PA }\end{array}$ \\
\hline 35. & $\begin{array}{l}\text { Moswete, Thapa, \& } \\
\text { Lacey (2009) [156] }\end{array}$ & Botswana & Village-based tourism and community participation \\
\hline $\begin{array}{l}36 . \\
37 . \\
38 .\end{array}$ & Nelson (2004) [77] & Tanzania & The evolution and impacts of community-based ecotourism \\
\hline 39. & $\begin{array}{l}\text { Nguangchaiyapoom, } \\
\text { Yongvanit, \& Sripun } \\
\quad(2012)[74]\end{array}$ & Thailand & $\begin{array}{l}\text { Development of CBT at with a specific focus on local } \\
\text { management practices }\end{array}$ \\
\hline 40. & $\begin{array}{l}\text { Nyaupane, Morais, \& } \\
\text { Dowler (2006) [157] }\end{array}$ & Nepal & 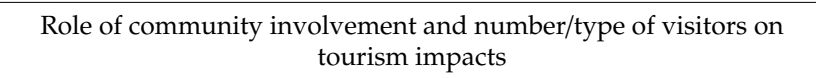 \\
\hline 41. & Ogutu (2002) [107] & Kenya & $\begin{array}{l}\text { Impact of ecotourism on livelihoods and natural } \\
\text { resource management }\end{array}$ \\
\hline 42. & Okazaki (2008) [33] & Philippines & Development and application of a CBT model \\
\hline 43. & $\begin{array}{l}\text { Paimin et al. } \\
\text { (2014) [158] }\end{array}$ & Malaysia & Community participation and barriers in rural tourism \\
\hline 44. & $\begin{array}{c}\text { Pawson, D'Arcy, \& } \\
\text { Richardson (2017) [159] }\end{array}$ & Cambodia & $\begin{array}{c}\text { Community's attitudes, opinions, and beliefs concerning the } \\
\text { contribution of CBT }\end{array}$ \\
\hline 45. & Prachvuthy (2006) [91] & Cambodia & Distribution of community-based tourism income in the community \\
\hline 46. & $\begin{array}{l}\text { Ramos \& Prideaux } \\
\quad(2014)[90]\end{array}$ & Mexico & Issues related to the level of Indigenous community empowerment \\
\hline 47. & $\begin{array}{l}\text { Reimer \& Walter } \\
\text { (2013) [116] }\end{array}$ & Cambodia & $\begin{array}{l}\text { Application of an analytical framework for "authentic" ecotourism to } \\
\text { examine the social dimensions of ecotourism }\end{array}$ \\
\hline $\begin{array}{l}48 . \\
49 . \\
50 .\end{array}$ & Rozemeijer (2000) [92] & Tanzania & $\begin{array}{l}\text { ODA experiences and lessons learned from CBT development } \\
\text { and management }\end{array}$ \\
\hline 51. & $\begin{array}{l}\text { Saufi, O'Brien, \& } \\
\text { Wilkins (2014) [24] }\end{array}$ & Indonesia & $\begin{array}{c}\text { Community perceptions of obstacles to their participation in } \\
\text { tourism development }\end{array}$ \\
\hline 52. & Sebele (2010) [93] & Botswana & Benefits and challenges of CBT \\
\hline $\begin{array}{l}53 . \\
54 .\end{array}$ & $\begin{array}{l}\text { Somarriba-Chang \& } \\
\text { Gunnarsdotter } \\
\text { (2012) [124] }\end{array}$ & Nicaragua & $\begin{array}{l}\text { Factors for community participation in ecotourism and impact } \\
\text { on conservation }\end{array}$ \\
\hline 55. & $\begin{array}{l}\text { Stone \& Stone } \\
\quad(2011)[97]\end{array}$ & Botswana & Community participation in a CBT enterprise \\
\hline 56. & Ellis (2011) [160] & Cambodia & Role of community in successful implementation of CBT \\
\hline 57. & Southgate (2006) [161] & Kenya & $\begin{array}{l}\text { Vulnerability of communities and internal conflicts as barriers for } \\
\text { bottom-up CBT }\end{array}$ \\
\hline 58. & Stronza (2010) [125] & Peru & Relationship between ecotourism and commons management \\
\hline 59. & Sundjaya (2005) [75] & Indonesia & Mangrove conservation through ecotourism development \\
\hline 60. & $\begin{array}{l}\text { Timothy \& White } \\
\text { (1999) [55] }\end{array}$ & Belize & $\begin{array}{l}\text { Participatory planning and division of economic benefits in a } \\
\text { CBT initiative }\end{array}$ \\
\hline $\begin{array}{l}61 . \\
62 . \\
63 . \\
64\end{array}$ & Wunder (1999) [162] & Colombia/Peru & Link between tourism, local benefits, and incentives for conservation \\
\hline 65. & Yeboah (2013) [163] & Ghana & Community participation in ecotourism projects \\
\hline 66. & $\begin{array}{l}\text { Zanotti \& Chernela } \\
\quad(2008)[164]\end{array}$ & Brazil & Conventions of education as a form of empowerment in ecotourism \\
\hline
\end{tabular}


Table A1. Cont.

\begin{tabular}{|c|c|c|c|}
\hline No. & Author(s) & Location & Focus of the Study \\
\hline \multicolumn{4}{|c|}{ DEVELOPED NATIONS } \\
\hline 67. & Albrecht (2010) [165] & New Zealand & $\begin{array}{c}\text { Challenges in tourism strategy implementation in } \\
\text { peripheral destinations }\end{array}$ \\
\hline 68. & $\begin{array}{l}\text { Ateljevic \& Doorne } \\
\quad(2003)[166]\end{array}$ & Croatia & Small-scale tourism entrepreneurship \\
\hline 69. & Berry (2006) [126] & USA & Lesions from small-scale tourism development \\
\hline 70. & Butler (2014) [164] & UK & Bird watching tourism in the countryside \\
\hline 71. & Casey (2003) [127] & Ireland & Small-scale village tourism development \\
\hline 72. & $\begin{array}{l}\text { Colton \& Harris (2007) } \\
\text { [137] }\end{array}$ & Canada & Indigenous ecotourism's role in community development \\
\hline 73. & $\begin{array}{l}\text { Dyer, Aberdeen, \& } \\
\text { Schuler (2003) [68] }\end{array}$ & Australia & Tourism impacts on an Indigenous community \\
\hline 74. & Forde (2011) [134] & Norway & $\begin{array}{c}\text { Transforming impact of tourism (new images, narratives, } \\
\text { representations) in a village }\end{array}$ \\
\hline $\begin{array}{l}75 . \\
76 .\end{array}$ & $\begin{array}{l}\text { George, Mair, \& Reid } \\
\text { (2009) [128] }\end{array}$ & Canada & Small-scale rural tourism development \\
\hline 77. & $\begin{array}{l}\text { Hashimoto \& Telfer } \\
\text { (2011) [89] }\end{array}$ & Japan & Female empowerment through agritourism in a rural area \\
\hline 78. & $\begin{array}{l}\text { Idziak, Majewski, \& } \\
\text { Zmyślony (2015) [165] }\end{array}$ & Poland & $\begin{array}{l}\text { Role of community involvement in } \\
\text { theme village development }\end{array}$ \\
\hline 79. & $\begin{array}{l}\text { Kastenholz et al. } \\
\quad \text { (2012) [46] }\end{array}$ & Portugal & Use of heritage and traditions in rural tourism in a village \\
\hline 80. & Keyim (2018) [69] & Finland & $\begin{array}{l}\text { Tourism collaborative governance } \\
\text { and rural community development }\end{array}$ \\
\hline $\begin{array}{l}81 . \\
82 .\end{array}$ & Kneafsey (2000) [58] & $\begin{array}{l}\text { France } \\
\text { Ireland }\end{array}$ & 'Bottom-up' tourism development in peripheral rural locations \\
\hline 83. & Macleod (2004) [70] & Spain & Changes inflicted by tourism development in island communities \\
\hline 84. & $\begin{array}{l}\text { Marsh \& Barre } \\
\text { (2006) [135] }\end{array}$ & Canada & $\begin{array}{l}\text { Planning, development, impact, and management of small-scale } \\
\text { tourism in a cold-water island location }\end{array}$ \\
\hline 85. & $\begin{array}{l}\text { Milne, Ward, \& Wenzel } \\
\text { (1995) [166] }\end{array}$ & Canada & $\begin{array}{l}\text { Key issues to strengthening the links between tourism and the } \\
\text { region's arts }\end{array}$ \\
\hline 86. & Monaghan (2012) [82] & Australia & $\begin{array}{l}\text { Response of indigenous communities to threats and challenges posed } \\
\text { by commercialization of culture }\end{array}$ \\
\hline 87. & $\begin{array}{l}\text { Müller \& Huuva } \\
\quad \text { (2009) [78] }\end{array}$ & Sweden & $\begin{array}{c}\text { Constraints preventing an indigenous community getting more } \\
\text { involved in tourism development }\end{array}$ \\
\hline 88. & $\begin{array}{l}\text { Otterstad, Capota, \& } \\
\text { Simion (2011) [167] }\end{array}$ & Romania & $\begin{array}{l}\text { Project aimed at sustainable tourism to } \\
\text { counteract an ongoing extinction of a fish species }\end{array}$ \\
\hline $\begin{array}{l}89 . \\
90 .\end{array}$ & $\begin{array}{l}\text { Rockett \& Ramsey } \\
\quad(2017)[45]\end{array}$ & Canada & Resident perceptions of rural tourism development \\
\hline 91. & $\begin{array}{l}\text { Ruiz-Ballesteros \& } \\
\text { Caceres-Feria } \\
\text { (2016) [109] }\end{array}$ & Spain & $\begin{array}{l}\text { Participation of amenity migrants in the development of CBT and the } \\
\text { effect on community building }\end{array}$ \\
\hline 92. & $\begin{array}{l}\text { Salvatore, Chiodo, \& } \\
\text { Fantini (2018) [52] }\end{array}$ & Italy & $\begin{array}{l}\text { Governance and transition within the tourist supply in peripheral } \\
\text { rural areas }\end{array}$ \\
\hline 93. & Silva (2015) [110] & Portugal & $\begin{array}{l}\text { Ecotourism at the community-level: Governance of resources, } \\
\text { economic sustainability, cultural identity, and social relations }\end{array}$ \\
\hline 94. & $\begin{array}{l}\text { Strickland-Munro \& } \\
\text { Moore (2013) [83] }\end{array}$ & Australia & $\begin{array}{l}\text { Indigenous involvement and benefits from } \\
\text { tourism in protected areas }\end{array}$ \\
\hline 95. & $\begin{array}{l}\text { Trau \& Bushell } \\
\quad \text { (2008) [80] }\end{array}$ & Australia & Operation of an indigenous CBT enterprise \\
\hline 96. & $\begin{array}{l}\text { Tsaur, Lin, \& Lin } \\
\quad(2006)[168]\end{array}$ & Taiwan & $\begin{array}{l}\text { Evaluation of ecotourism sustainability from the integrated } \\
\text { perspective of resource, community, and tourism }\end{array}$ \\
\hline 97. & $\begin{array}{l}\text { Vafadari, Cooper, \& } \\
\text { Nakamuran (2014) [136] }\end{array}$ & Japan & Rural tourism and regional revitalization \\
\hline 98. & $\begin{array}{l}\text { Valaoras, Pistolas, \& } \\
\text { Sotriopoulou (2002) [76] }\end{array}$ & Greece & Development of mountain rural tourism and nature conservation \\
\hline
\end{tabular}


Table A1. Cont.

\begin{tabular}{|c|c|c|c|}
\hline No. & Author(s) & Location & Focus of the Study \\
\hline 99. & Verbole (2000) [94] & Slovenia & $\begin{array}{l}\text { Social and political dimensions of the rural tourism } \\
\text { development process }\end{array}$ \\
\hline 100. & $\begin{array}{l}\text { Weinberg, Bellows, \& } \\
\text { Ekster (2002) [79] }\end{array}$ & New Zealand & $\begin{array}{l}\text { Ecological, economic, social, and political challenges faced by an } \\
\text { ecotourism initiative }\end{array}$ \\
\hline 101. & Waldren (1997) [129] & Spain & $\begin{array}{l}\text { Long term view of the changing significance of foreigners in local life } \\
\text { and the processes of identity-construction and de-construction }\end{array}$ \\
\hline 102. & $\begin{array}{l}\text { Wang, Cater, \& Low } \\
\text { (2016) [95] }\end{array}$ & Taiwan & Political challenges in community-based ecotourism \\
\hline 103. & $\begin{array}{l}\text { Wiltshier \& Cardow } \\
\quad \text { (2006) [169] }\end{array}$ & New Zealand & $\begin{array}{c}\text { Planning, development, impact, and management of small-scale } \\
\text { tourism in a cold-water island location }\end{array}$ \\
\hline
\end{tabular}

\section{References}

1. Weaver, D.B. Community-based tourism as strategic dead-end. Tour. Recreat. Res. 2010, 35, $206-208$. [CrossRef]

2. WWF [World Wildlife Fund]. Guidelines for Community-Based Ecotourism Development; WWF International: Gland, Switzerland, 2001.

3. Hall, C.M. Tourism: Rethinking the Social Science of Obility; Prentice-Hall: Harlow, UK, 2005.

4. Stronza, A.; Gordillo, J. Community views of ecotourism. Ann. Tour. Res. 2008, 35, 448-468. [CrossRef]

5. Ashley, C. Facilitating Pro-Poor Tourism with the Private Sector: Lessons Learned from 'Pro-Poor Tourism Pilots in Southern Africa'; Overseas Development Institute: London, UK, 2005.

6. Ashley, C.; Roe, D.; Goodwin, H. Pro-Poor Tourism Strategies: Making Tourism Work for the Poor: A Review of Experience; Overseas Development Institute: London, UK, 2001.

7. Asker, S.; Boronyak, L.; Carrard, N.; Paddon, M. Effective Community Based Tourism: A Best Practice Manual; Sustainable Tourism Cooperative Research Centre, Griffith University: Mount Gravatt, Australia, 2010.

8. APEIS-RISPO. Asia Pacific Environmental Innovative Strategies-Research on Innovative and Strategic Policy Options. In Good Practices Inventory on Community-Based Tourism in Protected Areas; APEIS-RISPO: Tokyo, Japan, 2006.

9. Baktygulov, S.; Raeva, D. Creating Value for all: Community-Based Tourism; United Nations Development Programme: New York, NY, USA, 2010.

10. Bello, F.G.; Carr, N.; Lovelock, B. Community participation framework for protected area-based tourism planning. Tour. Plan. Dev. 2016, 13, 469-485. [CrossRef]

11. Calanog, L.A.; Reyes, D.P.T.; Eugenio, V.F. Making Ecotourism Work. A Manual on Establishing Community-Based Ecotourism Enterprise (CBEE) in the Philippines; Japan International Cooperation Agency: Metro Manila, Philippines, 2012.

12. CTO. Caribbean Tourism Organization. Competing with the Best: Good Practices in Community-Based Tourism in the Caribbean; CTO: Bridgetown, Barbados, 2007.

13. Dixey, L. Inventory and Analysis of Community Based Tourism in Zambia; USAID: Lusaka, Zambia, 2005.

14. Hamzah, A.; Khalifah, Z. Handbook on Community Based Tourism: How to Develop and Sustain CBT; Asia-Pacific Economic Cooperation: Kuala Lumpur, Malaysia, 2009.

15. InWEnt-Capacity Building International Training Manual for Community-Based Tourism; InWEnt: Bonn, Germany, 2002.

16. Mountain Institute Community-Based Tourism for Conservation and Development: A Resource Kit; The Mountain Institute: Washington, DC, USA, 2000.

17. SNV Netherlands Development Organization. Asia Pro-Poor Sustainable Tourism Network. A Toolkit for Monitoring and Managing Community-Based Ttourism; Griffith University: Gold Coast, Australia, 2007.

18. UNWTO United Nations World Tourism Organization. Compendium of Best Practices and Recommendations for Ecotourism in Asia and the Pacific; UNWTO: Madrid, Philippines, 2012.

19. Goodwin, H.; Santilli, R. Communitybased Tourism: A Success? International Centre for Responsible Tourism; ICRT Occasional Paper; ICRT: Leeds, UK, 2009.

20. Armstrong, R. An Analysis of the Conditions for Success of Community Based Tourism Enterprises; ICRT Occasional Paper; ICRT: Leeds, UK, 2012. 
21. Blackman, A.; Foster, F.; Hyvonen, T.; Bronwyn, J.; Kuilboer, A.; Moscardo, G. Factors contributing to successful tourism development in peripheral regions. J. Tour. Stud. 2004, 15, 59-70.

22. Moscardo, G. Peripheral tourism development: Challenges, issues and success factors. Tour. Recreat. Res. 2005, 30, 27-43. [CrossRef]

23. Moscardo, G. The role of knowledge in good governance for tourism. In Tourist Destination Governance: Practice, Theory and Issues; Laws, E., Richins, H., Agrusa, J., Scott, N., Eds.; CABI: Wallingford, UK, 2011; pp. 67-80.

24. Saufi, A.; O'Brien, D.; Wilkins, H. Inhibitors to host community participation in sustainable tourism development in developing nations. J. Sustain. Tour. 2014, 22, 801-820. [CrossRef]

25. Wilson, S.; Fesenmaier, D.R.; Fesenmaier, J.; Van Es, J.C. Factors for success in rural tourism development. J. Travel Res. 2001, 40, 132-138. [CrossRef]

26. Zielinski, S.; Kim, S.I.; Botero, C.M.; Yanes, A. Factors that facilitate and inhibit community-based tourism initiatives in developing nations. Curr. Issues Tour. 2020, 23, 723-739. [CrossRef]

27. Tosun, C. Limits to community participation in the tourism development process in developing nations. Tour. Manag. 2000, 21, 613-633. [CrossRef]

28. Giampiccoli, A.; Jugmohan, S.; Mtapuri, O. Community-based tourism in rich and poor nations: Towards a framework for comparison. Afr. J. Phys. Health Educ. Recreat. Danc. 2015, 21, 1200-1216.

29. Dodds, R.; Ali, A.; Galaski, K. Mobilizing knowledge: Determining key elements for success and pitfalls in developing community-based tourism. Curr. Issues Tour. 2018, 21, 1547-1568. [CrossRef]

30. Simmons, D.G. Community participation in tourism planning. Tour. Manag. 1994, 15, 98-108. [CrossRef]

31. Tosun, C. Towards a typology of community participation in the tourism development process. Int. J. Tour. Hosp. 1999, 10, 113-134. [CrossRef]

32. Manyara, G.; Jones, E. Community-based tourism enterprises development in Kenya: An exploration of their potential as avenues of poverty reduction. J. Sustain. Tour. 2007, 15, 628-644. [CrossRef]

33. Okazaki, E. A community-based tourism model: Its conception and use. J. Sustain. Tour. 2008, 16, 511-529. [CrossRef]

34. Saayman, M.; Giampiccoli, A. Community-based and pro-poor tourism: Initial assessment of their relation to community development. Eur. J. Tour. Res. 2016, 12, 145-190.

35. Jugmohan, S.; Steyn, J.N. A pre-condition and evaluation and management model for community-based tourism. Afr. J. Phys. Health Educ. Recreat. Danc. 2015, 21, 1065-1084.

36. Mtapuri, O.; Giampiccoli, A. Interrogating the role of the state and nonstate actors in community-based tourism ventures: Toward a model for spreading the benefits to the wider community. S. Afr. Geogr. J. 2013, 95, 1-15. [CrossRef]

37. Spenceley, A. Local impacts of community-based tourism in Southern Africa. In Responsible Tourism: Critical Issues for Conservation and Development; Spenceley, A., Ed.; Earthscan: London, UK, 2008.

38. Peredo, A.M.; Chrisman, J.J. Toward a theory of community-based enterprise. Acad. Manag. Rev. 2006, 31, 309-328. [CrossRef]

39. Ruiz-Ballesteros, E. Keys for approaching community-based tourism. Gazeta de Antropologia, $2017,33$. Available online: http://hdl.handle.net/10481/44362 (accessed on 16 March 2020).

40. Piselli, F. Communities, places, and social networks. Am. Behav. Sci. 2007, 50, 867-878. [CrossRef]

41. OECD. Tourism strategies and rural Development. 1994. Available online: https://www.oecd.org/cfe/tourism/ 2755218.pdf (accessed on 6 April 2020).

42. Beeton, S. Community Development through Tourism; Landlinks Press: Collingwood, Victoria, Australia, 2006.

43. Oppermann, M. Rural tourism in Germany: Farm and rural tourism operators. In The Business of Rural Tourism; Page, S.J., Getz, D., Eds.; International Thomson Business Press: London, UK, 1997; pp. 108-119.

44. Priestley, G.K.; Canoves, G.; Segui, M.; Villarino, M. Legislative frameworks for rural tourism: Comparative studies from Spain. In Rural Tourism and Sustainable Business; Hall, D., Kirkpatrick, I., Mitchell, M., Eds.; Channel View: Toronto, ON, Canada, 2005; pp. 63-86.

45. Rockett, J.; Ramsey, D. Resident perceptions of rural tourism development: The case of Fogo Island and Change Islands, Newfoundland, Canada. J. Tour. Cult. Chang. 2017, 15, 299-318. [CrossRef]

46. Kastenholz, E.; Carneiro, M.; Marques, C.; Lima, J. Understanding and managing the rural tourism experience-The case of a historical village in Portugal. Tour. Manag. Perspect. 2012, 4, 207-214. [CrossRef] 
47. Gannon, A. Rural tourism as a factor in rural community economic development for economies in transition. J. Sustain. Tour. 1994, 2, 51-60. [CrossRef]

48. Lane, B.; Kastenholz, E. Rural tourism: The evolution of practice and research approache-towards a new generation concept? J. Sustain. Tour. 2015, 23, 1133-1156. [CrossRef]

49. Hall, C.M. Editorial: Pro-poor tourism: Do 'tourism exchanges benefit primarily the nations of the South'? Curr. Issues Tour. 2007, 10, 111-118. [CrossRef]

50. Müller, D.K.; Jansson, B. The difficult business of making pleasure peripheries prosperous: Perspectives on space, place and environment. In Tourism in Peripheries: Perspectives from the Far North and South; Muller, D.K., Jansson, B., Eds.; CABI: Wallingford, UK, 2007; pp. 3-18.

51. Fuller, D.; Buultjens, J.; Cummings, E. Ecotourism and indigenous micro-enterprise formation in northern Australia opportunities and constraints. Tour. Manag. 2005, 26, 891-904. [CrossRef]

52. Salvatore, R.; Chiodo, E.; Fantini, A. Tourism transition in peripheral rural areas: Theories, issues and strategies. Ann. Tour. Res. 2018, 68, 41-51. [CrossRef]

53. Brown, F.; Hall, D. (Eds.) Tourism in Peripheral Areas: Case Studies; Channel View: Clevedon, UK, 2000.

54. Botterill, D.; Owen, R.E.; Emanuel, L.; Foster, N.; Gale, T.; Nelson, C.; Selby, M. Perceptions from the periphery: The experience of Wales. In Tourism in Peripheral Areas: Case Studies; Brown, F., Hall, D., Eds.; Channel View Publications: Clevedon, UK, 2002; pp. 7-38.

55. Timothy, D.J.; White, K. Community-based ecotourism development on the periphery of Belize. Curr. Issues Tour. 1999, 2, 226-242. [CrossRef]

56. Albrecht, J.N. Challenges in tourism strategy implementation in peripheral destinations-The case of Stewart Island, New Zealand. Tour. Hosp. Plan. Dev. 2010, 7, 91-110. [CrossRef]

57. Creswell, J.W. Qualitative Inquiry and Research Design: Choosing Among Five Approaches; Sage: Thousand Oaks, CA, USA, 2013.

58. Kneafsey, M. Tourism, place identities and social relations in the European rural periphery. Eur. Urban Reg. Stud. 2000, 7, 35-50. [CrossRef]

59. Gascón, J. The limitations of community-based tourism as an instrument of development cooperation: The value of the Social Vocation of the Territory concept. J. Sustain. Tour. 2013, 21, 716-731. [CrossRef]

60. Ngo, T.; Lohmann, G.; Hales, R. Collaborative marketing for the sustainable development of community-based tourism enterprises: Voices from the field. J. Sustain. Tour. 2018, 26, 1325-1343. [CrossRef]

61. Walter, P. Gender analysis in community-based ecotourism. Tour. Recreat. Res. 2011, 36, 159-168. [CrossRef]

62. Bhatnagar, B.; Williams, A.C. Participatory Development and the World Bank: Potential Directions for Change; World Bank: Washington, DC, USA, 1992.

63. United Nations. Popular Participation in Decision Making for Development; United Nations: New York, NY, USA, 1975.

64. Saxena, G.; Ilbery, B. Integrated rural tourism. A border case study. Ann. Tour. Res. 2008, 35, $233-254$. [CrossRef]

65. Borges Lima, I.; d'Hauteserre, A.M. Community capitals and ecotourism for enhancing Amazonian forest livelihoods. Anatolia 2011, 22, 184-203. [CrossRef]

66. Clements, T.; John, A.; Nielsen, K.; Vicheka, C.; Sokha, E.; Piseth, M. Translinks Case Study: Tmatboey Community-Based Ecotourism Project, Cambodia; Wildlife Conservation Society TransLinks Program: Phnom Penh, Cambodia, 2008.

67. Cobbinah, P.B.; Black, R.; Thwaites, R. Ecotourism implementation in the Kakum Conservation Area, Ghana: Administrative framework and local community experiences. J. Ecotourism 2015, 14, 223-242. [CrossRef]

68. Dyer, P.; Aberdeen, L.; Schuler, S. Tourism impacts on an Australian indigenous community: A Djabugay case study. Tour. Manag. 2003, 24, 83-95. [CrossRef]

69. Keyim, P. Tourism Collaborative Governance and Rural Community Development in Finland: The Case of Vuonislahti. J. Travel Res. 2018, 57, 483-494. [CrossRef]

70. Macleod, D. Tourism, Globalisation and Cultural Change: An Island Community Perspective; Channel View Publications: Clevedon, UK, 2004.

71. Isaac, M.; Wuleka, K. Community-based ecotourism and livelihood enhancement in Sirigu, Ghana. Int. J. Humanit. Soc. Sci. 2012, 2, 97-108. 
72. Jamieson, W.; Sunalai, P. Sustainable tourism planning and management in Klong Khwang, Thailand. In Innovative Communities: People-Centred Approaches to Environmental Management in the Asia-Pacific Region; Velasquez, J., Ed.; United Nations University Press: Tokyo, Japan, 2005; pp. 158-181.

73. Kontogeorgopoulos, N.; Churyen, A.; Duangsaeng, V. Success factors in community-based tourism in Thailand: The role of luck, external support, and local leadership. Tour. Plan. Dev. 2014, 11, 106-124. [CrossRef]

74. Nguangchaiyapoom, S.; Yongvanit, S.; Sripun, M. Community-based tourism management of Ban Prasat, Non Sung District, Nakhon Ratchasima Province, Thailand. Manutsat Sangkomsaat Humanit. Soc. Sci. 2012, 29, 191-207.

75. Velasquez, J. (Ed.) Sundjaya Mangrove conservation through ecotourism development by the Bobongko people in the Togean Islands, Indonesia. In Innovative Communities: People-Centred Approaches to Environmental Management in the Asia-Pacific Region; United Nations University Press: Tokyo, Japan, 2005; pp. 182-203.

76. Valaoras, G.; Pistolas, K.; Sotriopoulou, H.Y. Ecotourism revives rural communities-The case of the Dadia Forest Reserve, Evros, Greece. Mt. Res. Dev. 2002, 22, 123-127. [CrossRef]

77. Nelson, F. The evolution and impacts of community-based ecotourism in northern Tanzania; Issue Paper; International Institute for Environment and Development: London, UK, 2004.

78. Müller, D.K.; Huuva, S.K. Limits to Sami tourism development: The case of Jokkmokk, Sweden. J. Ecotourism 2009, 8, 115-127. [CrossRef]

79. Weinberg, A.; Bellows, S.; Ekster, D. Sustaining ecotourism: Insights and implications from two successful case studies. Soc. Nat. Resour. 2002, 15, 371-380. [CrossRef]

80. Trau, A.M.; Bushell, R. Tourism and indigenous peoples. In Tourism, Recreation and Sustainability: Linking Culture and the Environment; McCool, S.F., Moisey, R.N., Eds.; CABI: Wallingford, UK, 2008; pp. 260-282.

81. Hall, C.M.; Boyd, S. Nature-based tourism in peripheral areas: Introduction. In Nature-Based Tourism in Peripheral Areas: Development or Disaster? Hall, C.M., Boyd, S., Eds.; Channel View: Clevedon, UK, 2005; pp. 3-17.

82. Monaghan, P. Going for Wombat-Transformations in Wirangu and the Scotdesco Community on the Far West Coast of South Australia. Oceania 2012, 82, 45-61. [CrossRef]

83. Strickland-Munro, J.; Moore, S. Indigenous involvement and benefits from tourism in protected areas: A study of Purnululu National Park and Warmun Community, Australia. J. Sustain. Tour. 2013, 21, $26-41$. [CrossRef]

84. Anand, A.; Chandan, P.; Singh, R.B. Homestays at Korzok: Supplementing rural livelihoods and supporting green tourism in the Indian Himalayas. Mt. Res. Dev. 2012, 32, 126-136. [CrossRef]

85. Cole, S. Information and empowerment: The keys to achieving sustainable tourism. J. Sustain. Tour. 2006, 14, 629-644. [CrossRef]

86. Collins, S.; Snel, H. A perspective on community based tourism from South Africa: The TRANSFORM Programme, 1996-2007. In Responsible Tourism: Critical Issues for Conservation and Development; Spenceley, A., Ed.; Earthscan: London, UK, 2008; pp. 85-106.

87. Giampiccoli, A.; Jugmohan, S.; Mtapuri, O. International cooperation, community-based tourism and capacity building: Results from a Mpondoland village in South Africa. Mediterr. J. Soc. Sci. 2014, 5, 657-667. [CrossRef]

88. Grieves, M.; Adler, M.; King, R. To preserve the mountains and the community: Indigenous ecotourism as a sustainable development strategy. Soc. Thought Res. 2014, 33, 83-111. [CrossRef]

89. Hashimoto, A.; Telfer, D. Female empowerment through agritourism in rural Japan. In Tourism and Agriculture: New Geographies of Consumption, Production and Rural Restructuring; Torres, R.M., Momsen, J.H., Eds.; Routledge: London, UK; New York, NY, USA, 2011; pp. 72-83.

90. Ramos, A.M.; Prideaux, B. Indigenous ecotourism in the Mayan rainforest of Palenque: Empowerment issues in sustainable development. J. Sustain. Tour. 2013, 22, 461-479. [CrossRef]

91. Prachvuthy, M. Tourism, poverty, and income distribution: Chambok community-based ecotourism development, Kirirom National Park, Kompong Speu Province, Cambodia. J. Greater Mekong Subreg. Dev. Stud. 2006, 3, 25-40.

92. Rozemeijer, N. Community-Based Tourism in Botswana: The SNV Experience in 3 Community Tourism Projects; SNV/IUCN CBNRM Support Programme: Gaborone, Botswana, 2000. 
93. Sebele, L.S. Community-based tourism ventures, benefits and challenges: Khama Rhino Sanctuary Trust, Central District, Botswana. Tour. Manag. 2010, 31, 136-146. [CrossRef]

94. Verbole, A. Actors, discourses and interfaces of rural tourism development at the local community level in Slovenia: Social and political dimensions of the rural tourism development process. J. Sustain. Tour. 2000, 8, 479-490. [CrossRef]

95. Wang, C.C.; Cater, C.; Low, T. Political challenges in community-based ecotourism. J. Sustain. Tour. 2016, 24, 1555-1568. [CrossRef]

96. Novelli, M.; Gebhardt, K. Community based tourism in Namibia: 'Reality show' or 'window dressing'? Curr. Issues Tour. 2007, 10, 443-479. [CrossRef]

97. Stone, L.S.; Stone, T.M. Communitybased tourism enterprises: Challenges and prospects for community participation; Khama Rhino Sanctuary Trust, Botswana. J. Sustain. Tour. 2011, 19, 97-114. [CrossRef]

98. Chili, N.S.; Ngxongo, N.A. Challenges to active community involvement in tourism development at Didima Resort: A case study of Umhlwazini community in Bergville. Afr. J. Hosp. Tour. Leis. 2017, 6, 1-15.

99. Marzuki, A.; Hay, I.; James, J. Public participation shortcomings in tourism planning: The case of the Langkawi Islands, Malaysia. J. Sustain. Tour. 2012, 20, 585-602. [CrossRef]

100. Sharpley, R.; Telfer, D.J. Tourism and Development: Concepts and Issues; Channel View Publications: Clevendon, UK, 2002.

101. Getz, D.; Jamieson, W. Rural tourism in Canada: Issues, opportunities and entrepreneurship in aboriginal tourism in Alberta. In The Business of Rural Tourism: International Perspectives; Page, S., Getz, D., Eds.; International Thomson Business Press: London, UK, 1997; pp. 93-107.

102. Bramwell, B.; Lane, B. Sustainable tourism and the evolving roles of government planning. J. Sustain. Tour. 2010, 18, 1-5. [CrossRef]

103. Yanes, A.; Zielinski, S.; Díaz Cano, M.; Kim, S.I. Community-based tourism in developing nations: A framework for policy evaluation. Sustainability 2019, 11, 2506. [CrossRef]

104. Ruhanen, L. Local government: Facilitator or inhibitor of sustainable tourism development? J. Sustain. Tour. 2013, 21, 80-98. [CrossRef]

105. Ritchie, J.R.; Crouch, G.I. The Competitive Destination: A Sustainable Tourism Perspective; CABI Publishing: Cambridge, UK, 2003.

106. Charnley, S. From nature tourism to Ecotourism? The case of the Ngorongoro Conservation Area, Tanzania. Hum. Organ. 2005, 64, 75-88. [CrossRef]

107. Ogutu, Z.A. The impact of ecotourism on livelihood and natural resource management in Eselenkei, Amboseli ecosystem, Kenya. Land Degrad. Dev. 2002, 13, 251-256. [CrossRef]

108. Berry, T. Nuvinak Island, Alaska. In Extreme Tourism: Lessons from the World's Cold Water Islands; Baldacchino, G., Ed.; Elsevier: Amsterdam, The Netherlands, 2006; pp. 64-73.

109. Ruiz-Ballesteros, E.; Caceres-Feria, R. Community-building and amenity migration in community-based tourism development. An approach from southwest Spain. Tour. Manag. 2016, 54, 513-523. [CrossRef]

110. Silva, L. How ecotourism works at the community-level: The case of whale-watching in the Azores. Curr. Issues Tour. 2015, 18, 196-211. [CrossRef]

111. Fletcher, C.; Pforr, C.; Brueckner, M. Factors influencing Indigenous engagement in tourism development: An international perspective. J. Sustain. Tour. 2016, 24, 1100-1120. [CrossRef]

112. Nilsson, P.A. Tourism's role in new rural policy for peripheral areas: The case of Arjeplog. In Tourism in Peripheral Areas: Case Studies; Brown, F., Hall, D., Eds.; Channel View: Clevedon, UK, 2000; pp. 133-151.

113. Bramwell, B. Governance, the state and sustainable tourism: A political economy approach. J. Sustain. Tour. 2011, 19, 459-477. [CrossRef]

114. Bruyere, B.L.; Beh, A.W.; Lelengula, G. Differences in perceptions of communication, tourism benefits, and management issues in a protected area of rural Kenya. Environ. Manag. 2009, 43, 49-59. [CrossRef]

115. Lenao, M. Challenges facing community-based cultural tourism development at Lekhubu Island, Botswana: A comparative analysis. Curr. Issues Tour. 2015, 18, 579-594. [CrossRef]

116. Reimer, J.K.; Walter, P. How do you know it when you see it? Community-based ecotourism in the Cardamom Mountains of southwestern Cambodia. Tour. Manag. 2013, 34, 122-132. [CrossRef]

117. Coria, J.; Calfucura, E. Ecotourism and the development of indigenous communities: The good, the bad, and the ugly. Ecol. Econ. 2012, 73, 47-55. [CrossRef] 
118. Jitpakdee, R.; Thapa, G.B. Sustainability analysis of ecotourism on Yao Noi Island, Thailand. Asia Pac. J. Tour. Res. 2012, 17, 301-325. [CrossRef]

119. Nepal, S.K. Indigenous ecotourism in central British Columbia: The potential for building capacity in the Tl'azt'en nations territories. J. Ecotourism 2004, 3, 173-194. [CrossRef]

120. Moswete, N.; Thapa, B.; Child, B. Attitudes and opinions of local and national public sector stakeholders towards Kgalagadi Transfrontier Park, Botswana. Int. J. Sustain. Dev. World Ecol. 2012, 19, 67-80. [CrossRef]

121. Avila Foucat, V.S. Community-based ecotourism management moving towards sustainability, in Ventanilla, Oaxaca, Mexico. Ocean Coast. Manag. 2002, 45, 511-529. [CrossRef]

122. Colvin, J.G. Capirona: A model of indigenous ecotourism. J. Sustain. Tour. 1994, 2, 174-177. [CrossRef]

123. Lepp, A. Residents' attitudes towards tourism in Bigodi village, Uganda. Tour. Manag. 2007, 28, 876-885. [CrossRef]

124. Somarriba-Chang, M.; Gunnarsdotter, Y. Local community participation in ecotourism and conservation issues in two nature reserves in Nicaragua. J. Sustain. Tour. 2012, 20, 1025-1043. [CrossRef]

125. Stronza, A. Commons management and ecotourism: Ethnographic evidence from the Amazon. Int. J. Commons 2010, 4, 56-77. [CrossRef]

126. Zanotti, L.; Chernela, J. Conflicting cultures of nature: Ecotourism, education and the Kayapó of the Brazilian Amazon. Tour. Geogr. 2008, 10, 495-521. [CrossRef]

127. Casey, R. Defining the local: The development of an 'environment culture' in a Clare Village. In Irish Tourism: Image, Culture and Identity; Cronin, M., O'Connor, B., Eds.; Channel View: Clevedon Hall, UK, 2003; pp. 42-60.

128. George, E.W.; Mair, H.; Reid, D.G. Rural Tourism Development: Localism and Cultural Change; Channel View Publications: Bristol, UK, 2009.

129. Waldren, J. We are not tourists-We live here. In Tourists and Tourism: Identifying with People and Places; Abram, S., Waldren, J.D., Macleod, D.V.L., Eds.; Oxford International: Oxford, UK; New York, NY, USA, 1997; pp. 51-70.

130. Jamal, T.B.; Stronza, A. Collaboration theory and tourism practice in protected areas: Stakeholders, structuring and sustainability. J. Sustain. Tour. 2009, 17, 169-189. [CrossRef]

131. Lapeyre, R. Community-based tourism as a sustainable solution to maximise impacts locally? The Tsiseb Conservancy case, Namibia. Dev. S. Afr. 2010, 27, 757-772. [CrossRef]

132. Mitchell, R.E.; Eagles, P.F.J. An integrative approach to tourism: Lessons from the Andes of Peru. J. Sustain. Tour. 2001, 9, 4-28. [CrossRef]

133. Ateljevic, I.; Doorne, S. Unpacking the local: A cultural analysis of tourism entrepreneurship in Murter, Croatia. Tour. Geogr. 2003, 5, 123-150. [CrossRef]

134. Forde, A. From fishing industry to 'fish porn': Tourism transforming place. In Sustainable Tourism in Rural Europe: Approaches to Development; Macleod, D.V.L., Gillespie, S.A., Eds.; Routledge: Oxon, UK; New York, NY, USA, 2011; pp. 196-209.

135. Marsh, S.; Barre, d.1.S. Bank Island, Northwest Territories, Canada. In Extreme Tourism: Lessons from the World's Cold Water Islands; Baldacchino, G., Ed.; Elsevier: Amsterdam, The Netherlands, 2006; pp. 75-86.

136. Vafadari, K.; Cooper, M.; Nakamura, K. Rural tourism and regional revitalization in Japan: A spotlight on Satoyama. In Rural Tourism: An International Perspective; Dashper, K., Ed.; Cambridge Scholars: Newcastle, UK, 2014; pp. 337-360.

137. Colton, J.; Harris, S. Indigenous ecotourism's role in community development: The case of the Lennox Island First Nation. In Tourism and Indigenous Peoples: Issues and Implications; Butler, R., Hinch, R., Eds.; Elsevier: Oxford, UK; Burlington, MA, USA, 2007; pp. 220-233.

138. Hiwasaki, L. Community-based tourism: A pathway to sustainability for Japan's protected areas. Soc. Nat. Resour. 2006, 19, 675-692. [CrossRef]

139. Iorio, M.; Corsale, A. Communitybased tourism and networking: Viscri, Romania. J. Sustain. Tour. 2014, 22, 234-255. [CrossRef]

140. Matarrita-Cascante, D.; Luloff, A.E.; Krannich, R.S.; Field, D.R. Community participation in rapidly growing communities in Southern Utah. Community Dev. 2006, 37, 71-87. [CrossRef]

141. Matarrita-Cascante, D.; Stocks, G. Amenity migration to the global south: Implications for community development. Geoforum 2013, 49, 91-102. [CrossRef]

142. Coles, T.; Scherle, N. Prosecuting power: Tourism, inter-cultural communications and the tactics of empowerment. In Tourism, Power and Space, 1st ed.; Church, A., Coles, T., Eds.; Routledge: London, UK, 2007. 
143. Kopper, E. Multicultural workgroups and project teams. In Interkulturelles Management; Bergemann, N., Sourisseaux, A., Eds.; Physica: Heidelberg, Germany, 1992; pp. 229-251.

144. Matarrita-Cascante, D.; Brennan, M. Conceptualizing community development in the 21st century. Community Dev. 2012, 43, 293-305. [CrossRef]

145. Wilkinson, K.P. The Community in Rural America; Social Ecology Press: Middletown, WI, USA, 1991.

146. Mitchell, J.; Muckosy, P. A Misguided Quest: Community-Based Tourism in Latin America; ODI: London, UK, 2008.

147. Zielinski, S.; Jeong, Y.J.; Milanés, C. Factors that influence community-based tourism (CBT) in developing and developed countries. Tour. Geogr. 2020, in press. [CrossRef]

148. Carson, D.A. Challenges and opportunities for rural tourism geographies: A view from the 'boring' peripheries. Tour. Geogr. 2018, 20, 738-742. [CrossRef]

149. Amati, C. "We all voted for it": Experiences of participation in community-based ecotourism from the foothills of Mt Kilimanjaro. J. East. Afr. Stud. 2013, 7, 650-670. [CrossRef]

150. Belsky, J.M. Misrepresenting communities: The politics of community-based rural ecotourism in Gales Point Manatee, Belize. Rural Sociol. 1999, 64, 641-666. [CrossRef]

151. Hitchner, S.L.; Apu, F.L.; Tarawe, L.; Aran, S.G.N.; Yesaya, E. Community-based transboundary ecotourism in the heart of Borneo: A case study of the Kelabit Highlands of Malaysia and the Kerayan Highlands o Indonesia. J. Ecotourism 2009, 8, 193-213. [CrossRef]

152. Jones, S. Community-based ecotourism: The significance of social capital. Ann. Tour. Res. 2005, 32, $303-324$. [CrossRef]

153. Kim, S.; Park, E.; Phandanouvong, T. Barriers to local residents' participation in community-based tourism: Lessons from Houay Kaeng village in Laos. SHS Web Conf. 2014, 12, 1-8. [CrossRef]

154. Knight, D.W.; Cottrell, S.P. Evaluating tourism-linked empowerment in Cuzco, Peru. Ann. Tour. Res. 2016, 56, 32-47. [CrossRef]

155. Matarrita-Cascante, D.; Brennan, M.A.; Luloff, A.E. Community agency and sustainable tourism development: The case of La Fortuna, Costa Rica. J. Sustain. Tour. 2010, 18, 735-756. [CrossRef]

156. Moswete, N.; Thapa, B.; Lacey, G. Village-based tourism and community participation: A case study of the Matsheng villages in southwest Botswana. In Sustainable Tourism in Southern Africa: Local Communities and Natural Resources in Transition; Saarinen, J., Becker, F., Manwa, H., Wilson, D., Eds.; Channelview: Clevedon, UK, 2009; pp. 189-209.

157. Nyaupane, G.P.; Morais, D.B.; Dowler, L. The role of community involvement and number/type of visitors on tourism impacts: A controlled comparison of Annapurna, Nepal and Northwest Yunnan, China. Tour. Manag. 2006, 27, 1373-1385. [CrossRef]

158. Paimin, N.F.V.; Modilih, S.; Mogindol, S.H.; Johnny, C.; Thamburaj, J.A. Community participation and barriers in rural tourism: A case study in Kiulu, Sabah. Web Conf. 2014, 12, 1-7.

159. Pawson, S.; D'Arcy, P.; Richardson, S. The value of community-based tourism in Banteay Chhmar, Cambodia. Tour. Geogr. 2017, 19, 378-397. [CrossRef]

160. Ellis, S. Community Based Tourism in Cambodia: Exploring the Role of Community for Successful Implementation in Least Developed Countries. Ph.D. Thesis, Edith Cowan University, Joondalup, Australia, 2011. Available online: http://ro.ecu.edu.au/theses/451 (accessed on 16 October 2019).

161. Southgate, C.R.J. Ecotourism in Kenya: The vulnerability of communities. J. Ecotourism 2006, 5, 80-96. [CrossRef]

162. Wunder, S. Promoting forest conservation through ecotourism income? A case study from the Ecuadorian Amazon region. In Occasional Paper; Center for International Forestry Research: Jakarta, Indonesia, 1999.

163. Yeboah, T. Assessing community participation in selected ecotourism projects in the Brong-Ahafo Region, Ghana. J. Ecol. Nat. Environ. 2013, 5, 133-143.

164. Butler, R.W. Understanding the place of bird watching in the countryside: Lessons from Fair Isle. In Rural Tourism: An International Perspective; Dashper, K., Ed.; Cambridge Scholars: Newcastle, UK, 2014; pp. 322-336.

165. Idziak, W.; Majewski, J. Zmyślony, P. Community participation in sustainable rural tourism experience creation: A long-term appraisal and lessons from a thematic villages project in Poland. J. Sustain. Tour. 2015, 23, 1341-1362. [CrossRef]

166. Milne, S.; Ward, S.; Wenzel, G. Linking tourism and art in Canada's eastern Arctic: The case of Cape Dorset. Polar Rec. 1995, 31, 25-36. [CrossRef] 
167. Otterstad, O.; Capota, P.A.; Simion, A. Beluga Sturgeon Community Based Tourism (Best Combat). J. Coast. Res. 2011, 183-193. [CrossRef]

168. Tsaur, S.H.; Lin, Y.C.; Lin, J.H. Evaluating ecotourism sustainability from the integrated perspective of resource, community and tourism. Tour. Manag. 2006, 27, 640-653. [CrossRef]

169. Wiltshier, P.; Cardow, A. Extreme Tourism: Lessons from the World's Cold Water Islands; Baldacchino, G., Ed.; Elsevier: Amsterdam, The Netherlands, 2006; pp. 205-216. 